\title{
HUKUM NAFKAH TERHADAP KELUARGA PADA GERAKAN TRANSNASIONAL KEAGAMAAN
}

\author{
Muhamad Bisri Mustofa \\ Institut Agama Islam Agus Salim Metro \\ Jl. Brigjend. Sutiyoso No. 7, Kota Metro, 34111, Lampung \\ muhamadbisrimustofa@gmail.com
}

\begin{abstract}
Since the emergence of the Transnational Da'wah Movement such as the Tablighi Jama'at, it has created contradictions about the Law of Providing both birth and mentality to the family left in the Khuruj fii sabilillah program (Exiting the Way of Allah) to preach the ummah from house to house, mosque to mosque, inviting listen to Muslims (religious lectures) and invite to pray in congregation in the mosque. From the development of Jama'ah Tabligh's missionary movement in Indonesia, this movement has experienced quite rapid development. Not only is the movement that has a Jama'at quite rapidly, it is marked by the presence of da'wah markers (da'wah centers) in each Province and District of the City. But in the development of the da'wah movement there are several things that become contradictions in the family, in this case the provision of income to children and wives who are left behind when their household heads implement Khuruj fi sabilillah for 3 days, 40 days and 4 months. Therefore, this paper takes the theme of the Law of Livelihood Against Families in the Tabligh Jama Da'wah Movement in a comprehensive manner.
\end{abstract}

Keywords: Family Livelihood, Religious Transnational Movement.

\begin{abstract}
Abstrak
Sejak Munculnya Gerakan Dakwah Transnasional seperti Jama'ah Tabligh menimbulkan kontradiksi tentang Hukum Memberikan Nafkah baik lahir maupun batin terhadap keluarga yang di tinggalkan dalam program Khuruj fii sabilillah (Keluar di Jalan Allah) untuk berdakwah mendatangi ummat dari rumah ke rumah, masjid ke masjid, mengajak mendengarkan ta'lim (ceramah agama) dan mengajak melaksanakan sholat berjamaa'h di masjid. Dari perkembangan gerakan dakwah Jama'ah Tabligh ini di Indonesia, gerakan ini telah mengalami perkembangan yang cukup pesat. Tidak saja menjadi gerakan yang memiliki Jama'ah cukup pesat ditandai dengan adanya markaz dakwah (pusat dakwah) disetiap Provinsi dan Kabupaten Kota. Namun dalam perkembangan gerakan dakwah tersebut terdapat beberapa hal yang menjadi kontradiksi dalam keluarga, dalam hal ini adalah pemberian nafkah kepada anak dan istri yang di tinggalkan ketika kepala rumah tangga mereka melaksanakan Khuruj fii sabilillah selama 3 hari, 40 hari dan 4 bulan.

Oleh sebab itu, tulisan ini mengambil tema Hukum Nafkah Terhadap Keluarga pada Gerakan Dakwah Jama'ah Tabligh secara komprehensif.
\end{abstract}

Kata Kunci: Nafkah Keluarga, Gerakan Transnasional Keagamaan.

\section{Pendahuluan}

Dalam perjalanan manusia kepada kebahagian hidup di dunia dengan berkeluarga, memiliki pendamping hidup dan keturunan. Pernikahan merupakan salah satu bentuk ibadah dan bagian dari pada ibadah terpanjang seorang Hamba. Pernikahan juga merupakan peristiwa hukum yang sangat penting dalam 
kehidupan manusia dengan berbagai konep hukumnya. ${ }^{1}$ Karena itu hukum mengatur masalah pernikahan ini secara detail. Yang dimaksud dengan perkawinan adalah suatu ikatan lahir dan batin antara seorang pria dan wanita sebagai suami istri dengan tujuan untuk membentuk suatu kelurga (rumah tangga) yang bahagia dan kekal berdasarkan ketuhanan yang maha esa, yang harus juga dicatat menurut peraturan perundang-undangan yang berlaku. Lihat pasal 1 dan pasal 2 undang-undang Perkawinan No. 1 Tahun 1974. ${ }^{2}$

Perkawinan dalam Islam diatur sedemikian rupa, oleh karena itu perkawinan sering disebut sebagai perjanjian suci antara seorang laki-laki dan seorang perempuan untuk membentuk keluarga yang bahagia. Salah satu tujuan syariah Islam (Maqasid Al-Syari'ah) sekaligus tujuan perkawinan adalah hifz an-nasl terpeliharanya kesucian keturunan manusia sebagai pemegang amanah khalifah fi al-ard. Tujuan syariah ini dapat dicapai melalui jalan perkawinan yang sah meurut agama, diakui oleh undang-undang dan diterima sebagai bagian dari budaya masyarakat. ${ }^{3}$ Dalam pandangan Islam perkawinan itu bukanlah hanya urusan perdata semata, bukan pula sekedar urusan keluarga dan masalah budaya, tetapi masalah dan peristiwa agama, oleh karena perkawinan itu dilakukan untuk memenuhi sunnah Allah dan sunnah Nabi dan dilaksanakan sesuai dengan petunjuk Allah dan petunjuk Nabi. Disamping itu, perkawinan juga bukan untuk mendapatkan ketenangan hidup sesaat, tetapi untuk selama hidup. ${ }^{4}$

Dengan adanya perkawinan maka timbulah hak dan kewajiban suami istri dalam rumah tangga, yang dimaksud dengan hak disini adalah apa-apa yang diterima oleh seseorang dari orang lain, sedangkan yang dimaksud dengan kewajiban adalah apa yang mesti dilakukan seseorang terhadap orang lain. Dalam hubungan suami istri dalam rumah tangga suami mempunyai hak dan begitu pula istri mempunyai hak. Dibalik itu suami mempunyai beberapa kewajiban dan begitu pula si istri mempunyai beberapa kewajiban. ${ }^{5}$ Sebagaimana firman Allah dalam alQur'an surat al-Baqarah ayat 228:

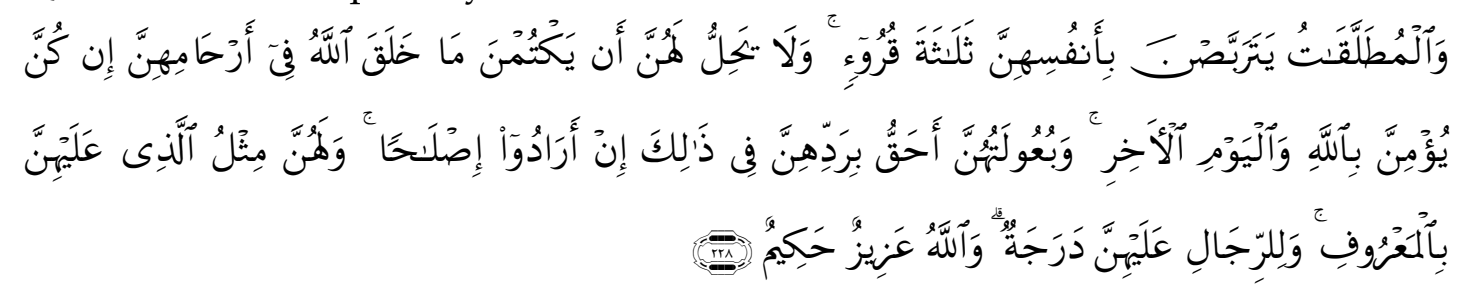

Artinya : "Wanita-wanita yang ditalak handaklah menahan diri (menunggu) tiga kali quru'6. tidak boleh mereka Menyembunyikan apa yang diciptakan Allah dalam rahimnya, jika mereka beriman kepada Allah dan hari akhirat. dan suami-suaminya berhak merujukinya dalam masa menanti itu, jika mereka (para suami) menghendaki ishlah. dan Para wanita mempunyai hak yang seimbang dengan kewajibannya menurut cara yang

1 Muhamad Bisri Mustofa, Hukum Nafkah Terhadap Keluarga Pada Gerakan Dakwah Jama'ah Tabligh, (Pascasajana IAIN, Metro, 2019), Vol. 7, No. 1 (2019), h. 2

2 Munir Fuady, Konsep Hukum Perdata, PT Raja Grafindo Persada, (Jakarta: 2014), h. 10.

3 Ahmad Rofiq, Hukum Isslam di Indoneia, cet. Ke-2, (Jakarta: PT Raja Grafindo Persada, 1997),

h. 220

4 Syariffuddun Amir, Hukum Perkawinan Islam di Indonesia, (Jakarta: Kencana, 2014), h. 48.

5 Ibid., h. 159.

6 Quru' dapat diartikan suci atau haidh. 
ma'ruf. akan tetapi Para suami, mempunyai satu tingkatan kelebihan daripada isterinya ${ }^{7}$ dan Allah Maha Perkasa lagi Maha Bijaksana."8

Ayat ini menjelaskan bahwa istri mempunyai hak dan istri juga mempunyai kewajiban. Kewajiban istri merupakan hak bagi suami. Hak istri semisal hak suami yang dikatakan dalam ayat ini mengandung arti hak dan kedudukan istri semisal atau setara atu seimbang dengan hak dan kedudukan suami. Meskipun demikian, suami mempunyai kedudukan setingkat lebih tinggi, yaitu sebagai kepala keluarga, sebagaimana diisyaratkan oleh ujung ayat tersebut diatas.

Mekanisme nafkah dalam Kompilasi Hukum Islam (KHI) terdapat dalam pasal 77 dan 78 .

\section{Pasal 77}

(1) Suami-istri memikul kewajiban yang luhur untuk menegakkan rumah tangga yang sakinah, mawaddah, dan rahmah yang menjadi sendi dasar dari susunan masyarakat.

(2) Suami-istri wajib saling cinta mencintai, hormat menghormati, setia dan memberi bantuan lahir batin yang satu kepada yang lain.

(3) Suami-istri memikul kewajiban untuk mengasuh dan memelihara anakanak mereka, baik mengenai pertumbuhan jasmani, rohani maupun kecerdasanya dan pendidikan agamanya.

(4) Suami-istri wajib memelihara kehormatanya.

(5) Jika suami atau istri melalaikan kewajibanya, masing-masing dapat mengajukan gugatan kepada Pengadilan Agama.

\section{Pasal 78}

(1) Suami-istri mempunyai tempat kediaman yang tetap.

(2) Rumah kediaman yang dimaksud dalam Ayat (1), ditentukan oleh suamiistri bersama.

Pasal-pasal diatas menguraikan bahwa suami sebagai kepala rumah tangga adalah nahkoda dalam menjalankan rumah tangganya. Suami memiliki hak dan kewajiban, dan begitu pula istri. Masing-masing suami istri jika menjalankan kewajibanya dan memperhatikan tanggung jawabnya, akan terwujud ketentraman dan ketenangan hati sehingga sempurnalah kebahagiaan suami-istri tersebut. ${ }^{9}$

Menurut fitrah, laki-laki wajib menanggung semua urusan diluar rumah. Ini berlaku pada semua umat peradaban. Sedangkan wanita, menurut fitrahnya bertugas untuk mengandung anak, menyusuinnya, mengasuhnya dan mendidik mereka, selain mengurus perkara-perkara rumah tangga, wanita menguasai semua urusan internal rumah. ${ }^{10}$

Demikian pendapat As-Sayyid Muhammad Ridha. Nafaqah merupakan kewajiban suami terhadap istrinya dalam bentuk materi, karena kata nafaqah itu sendiri berkonotasi materi.11 Sedangkan yang termasuk dalam pengertian nafaqah menurut yang disepakati ulama' adalah sembilan bahan pokok pakaian dan

7 Hal ini disebabkan karena suami bertanggungjawab terhadap keselamatan dan Kesejahteraan rumah tangga (Lihat surat An Nisaa' ayat 34)

8 Departemen Agama RI, Al-Qur'an dan Terjemahannya, h. 36.

9 As-Sayyid Sabiq, Fiqih as-sunnah, alih bahasa. Moh Thalib, cet. Ke-13 (Bandung: Al-Ma'arif, 1997), VII, h. 51

10 As-Sayyid Muhammad Rasyid Ridha, Risalah Hak dan Kewajiban Wanita, alih bahasa Isnando (Jakarta: Pustaka Qalami, 2004), h. 53.

11 Op.Cit, Syariffuddun Amir, Hukum Perkawinan Islam di Indonesia..., h.165. 
perumahan atau dalam bahasa sehari-hari disebut sandang, pangan, dan papan selain dari tiga hal tersebut menjadi perbincangan di kalangan ulma'.12

Nafkah artinya mengelurkan belanja. Menurut istilah syara' artinya sesuatu yang dikeluarkan oleh seseorang untuk keperluan dirinya atau keluarganya yang berupa makanan, minuman, pakaian dan sebagainya. ${ }^{13}$ Yang menyebabkan wajib nafkah ialah : Sebab perkawinan yang sah, Sebab kerabat, Sebab milik.

Kewajiban memberikan nafaqah oleh suami kepada istrinya yang berlaku dalam fiqih didasarkan kepada prinsip pemisahan harta antara suami dan istri, prinsip ini mengikuti alur fikir bahwa suami itu adalah pencari rezeki, rezeki yang telah diperoleh itu menjadi haknya secara penuh dan untuk selanjutnya suami berkedudukan sebagai pemberi nafaqah. Sebaliknya istri bukan pencari rezeki dan untuk memenuhi keperluanya ia berkedudukan sebagai penerima nafaqah. ${ }^{14}$

Jumhur ulama termasuk ulama' Syi'ah imamiyah berpendapat bahwa nafaqah itu mulai diwajibkan semenjak dimulainya kehidupan rumah tangga, yaitu semenjak suami telah bergaul dengan istrinya dalam arti istri telah memberikan kemungkinan kepada suaminya untuk menggaulinya, yang dalam fiqih disebut dengan tamkin. Dengan semata terjadinya akan nikah belum ada kewajiban membayar nafaqah. Berdasarkan pendapat ini bila telah berlangsunya akad nikah istri belum melakukan tamkin karena keadaanya ia belum berhak menerima nafaqah. (al-Thusy, VI:11).15

Para ulama selain Hanafiyah berpendapat bahwa pernikahhan mewajibkan seorang suami memberikan nafkah, bahkan jika istri tersebut kafir, jika melalui pernikahan yang sah. Tetapi jika pernikahan itu fasid, maka suami berhak meminta nafkah yang telah diambil oleh istrinya. ${ }^{16}$

Menurut imam Asy-Safi'i, suami wajib memberikan nafkah harian, sebagai konsekuensi penyerahan istri kepada suami, kewajiban nafkan karena perkawinan ada tujuh macam, yaitu membeikan makan, memberikan pakaian, memberikan laukpauk, memberikan alat perawatan tubuh, memberikan rumah, memberikan perhiasan rumah, dan menyediakan pembantu jika memang istri membutuhkanya. ${ }^{17}$

Di Indonesia banyak bermunculan kelompok atau ormas Islam seperti LDII, HTI, Sidiqiyyah, FPI dan Jamah Tabligh. Namun penulis meneliti kelompok Jamaah Tabligh dikarenakan kelompok atau jamaah ini lebih aktif dibidang dakwah dengan metode yang dinamakan khuruj fii sabilillah (keluar di jalan Allah). Para jamaah terjun langsung kepada setiap elemen masyarakat dengan ketentuan kurun waktu secara bertahap 3 hari dalam setiap bulan, 40 hari dalam setiap tahun dan 4 bulan setiap tahun.

Ketika dalam masa berdakwah atau khuruj meninggalkan istri dan anakanaknya kewajiban sebagai kepela rumah tangga harus tetap terpenuhi salah satunya adalah kewajiban memberikan nafkah terhadap keluarganya.

Jadi kesejahteraan masyarakat sangat tergantung terhadap suami sebagai kepala keluarga yang mampu melaksanakan kewajiban nafkah terhadap istri dan

\footnotetext{
12 Ibid, Syariffuddun Amir, Hukum Perkawinan Islam di Indonesia..., h. 166.

13 Zainal Abidin S dan Ibnu Mas'ud, Fiqih Madzhab Syafi'I (Bandung: Pustaka Setia, 2007), h.

14 Ibid., Syariffuddun Amir, Hukum Perkawinan Islam di Indonesia..., h. 165

15 Ibid, Syariffuddun Amir, Hukum Perkawinan Islam di Indonesia..., h. 168.

16 Wahbah az-Zuhaili, Al-Figh Al-Islam Wa'dillatuhu jilid X Terrjemahan Abdul Hayyi al-Qotani dkk, (Jakarta: Gema Insani \& Darul Fikir, 2011), h. 110.

17 Wahbah Zuhaili, Al- Figh asy-Syafi'I al-'Ami, Terjemahan Muhammad Afifi dan Abdul Aziz, jilid III, cet. I, (Jakarta: Al-Mahira, 2010), h. 42
} 425. 
keluarganya, para ulama madzhab sepakat bahwa nafkah untuk istri itu wajib yang meliputi tiga hal pangan, sandang dan papan. ${ }^{18}$

\section{Nafkah \\ Pengertian}

Kata nafkah berasal dari bahasa Arab yakni anfaqa - yunfiqu- infaqan yang berarti الإخراج kata ini tidak digunakan kecuali untuk yang baik saja.. ${ }^{2}$ Adapun bentuk jama"-nya adalah نقات. secara bahasa berarti "Sesuatu yang dikeluarkan manusia untuk tanggungannya". Nafkah diambil dari kata "الانفاق" yang artinya mengeluarkan atau membelanjakan. ${ }^{20}$ Nafkah juga bisa bermakna belanja, yaitu sesuatu yang diberikan oleh suami kepada istrinya, seorang bapak kepada anaknya, dan seorang kerabat kepada pemiliknya sebagai keperluan pokok bagi mereka.21 Dalam pengertian yang lain kata nafkah berasal dari kata انْفَ kata ini tidak digunakan kecuali untuk yang baik saja.22 Kata nafaqah atau infaq hanya digunakan untuk pengertian positif. ${ }^{23}$ Dalam syariat, kata nafkah mengandung makna segala biaya hidup yang merupakan hak istri dan anak-anaknya dalam berbagai hal seperti makanan, pakaian, tempat kediaman serta beberapa kebutuhan pokok lainnya. Walaupun istri itu seorang wanita yang kaya. ${ }^{24}$ Adapun kesimpulan ulama terkait kewajiban nafkah yaitu menempatkan suami sebagai seorang yang dibebankan nafkah atas istrinya. Sementara itu, ketika suami telah dikaruniai anak, maka kewajiban itu bertambah kepada istrinya. ${ }^{25}$

Adapun bentuk jama"-nya adalah نفقات . secara bahasa berarti :

$$
\text { ما يُنفقُو الإنسانُ على عيالِ } 26
$$

"Sesuatu yang dikeluarkan manusia untuk tanggungannya"

Dalam kamus Arab-Indonesia, secara etimologi kata nafkah diartikan dengan pembelanjaan. ${ }^{27}$ Dalam tata bahasa Indonesia kata nafkah secara resmi sudah dipakai dengan arti pengeluaran. ${ }^{28}$ Adapun menurut istilah syara"e nafkah adalah:

$$
\text { كفاية مَن يمونو من الطعام والكسوة والسكنى } 29 \text {. }
$$

"Mencukupi kebutuhan orang yang menjadi tanggung jawabnya berupa makanan, pakaian, dan tempat tinggal."

$$
\text { ، ومصباح وغير ذلك الشخص مؤنة مَن بحبُ عليو نفقة من خبِ، وإدامٍ، وكسوة، ومسكن، وما يتبع ذلك من ثمنِ ماءِ، وددن }
$$

18 Muhammad Jawad Mugniyah, Figh Lima Mazhab, Cet. 12 (Jakarta: Lentera, 2001), h. 422.

19 Ibnu Manzhur. Lisãn al- Arab. Jilid. 4 ( Bairut: Dãr-Elfikr. 1990), h. 820

20 Aliy As'ad, Terjemahan Fat-Hul Mu'in, Jilid 3, Menara Kudus, t.t, h. 197

21 Syamsul Bahri, Konsep Nafkah dalam Hukum Islam, No. 66, Th. XVII (Agustus, 2015), h. 381

22 Syamsuddin Muhammad bin Muhamamd al-Khatin al-Syarbini, Mugni al-Muhtaj, (Bairut: Dar-al-Kutub al-Ilmiyah, tt), Juz V, h. 151

${ }^{23}$ Subaidi, Konsep Nafkah Menurut Hukum Perkawinan Islam, Vol. 1 No. 2 (Desember, 2014), h. 3

24 Ibid., Subaidi, Konsep Nafkah Menurut Hukum Perkawinan Islam..., hal. 3

25 Ibid., Subaidi, Konsep nafkah Menurut Hukum Perkawinan Islam..., hal. 160

26 Wahbah al-Zuhaili, al-Figh al-Islam wa Adillatuhu, (Beirut: Dar al-Fikr, 1989), jilid II, cet. II, h.

27 Ahmad Warson Munawir, Kamus al Munawwir, (Yogyakarta: Pondok Psantren al Munawwir, 1984), h. 1548

28 Diknas, Kamus Besar Bahasa Indonesia, (Jakarta: Balai Pustaka, 2002), Edisi ketiga, h. 770

29 Abdurrahman al-Jaziri, kitab al-Fiqh "ala Madzhabi al-Arba"ah, (Beirut: Dar al-Kutub al„Ilmiyah, 1969), juz. IV, h. 485

30 Op.cit., Wahbah al-Zuhaili, al-Figh al-Islam wa Adillatuhu..., h. 765

62

Al-Qudhi : Jurnal Hukum Keluarga Islam Vol. I, No. I (Juli 2019) 
"Pengeluaran seseorang atas sesuatu sebagai ongkos terhadap orang yang wajib dinafkahinya, terdiri dari roti, lauk-pauk, pakaian, tempat tinggal, dan apa yang mengikutinya seperti harga air, minyak, lampu dan lain-lain."

Mencermati beberapa definisi serta batasan tersebut di atas dapat dipahami, bahwa nafkah adalah pengeluaran yang biasanya dipergunakan oleh seseorang untuk orang yang menjadi tanggungannya dalam memenuhi kebutuhan hidup, baik berupa pangan, sandang ataupun papan dan lainnya dengan sesuatu yang baik.

Nafkah berasal dari bahasa arab annafaqàh artinya almasrufu walanfaqu yaitu biaya, belanja, pengeluaran uang. ${ }^{31}$ Sedangkan menurut istilah nafkah adalah kewajiban suami untuk memenuhi kebutuhan istri dalam menyediakan makanan, tempat tinggal, pembantu, dan obat-obatan, apabila suaminya kaya. ${ }^{32}$ Pengertian lain secara istilah nafkah adalah "Mencukupi kebutuhan orang yang menjadi tanggung jawabnya berupa makanan, pakaian, dan tempat tinggal", definisi lainnya "Pengeluaran seseorang atas sesuatu sebagai ongkos terhadap orang yang wajib dinafkahinya, terdiri dari roti, lauk-pauk, pakaian, tempat tinggal, dan apa yang mengikutinya seperti harga air, minyak, lampu dan lain-lain".

Sebuah perkawinan menimbulkan hak dan kewajiban antara suami dan istri. Diantara kewajiban suami terhadap istri yang paling pokok adalah kewajiban memberi nafkah, baik berupa makan, pakaian (kiswah), maupun tempat tinggal bersama. Dengan adanya pernikahan maka suami wajib menafkahi istrinya baik nafkah lahir maupun batin. Kewajiban suami adalah pembimbing, terhadap istri dan rumah tangganya, akan tetap mengenai hal-hal urusan rumah tangga yang pentingpenting diputuskan oleh sumai istri bersama. Suami wajib melidungi istrinya dan memberikan segala sesuatu keperluan hidup berumah tangga sesuai dengan kemampuannya. Suami wajib memberikan pendidikan agama kepada isterinya dan memberi kesempatan belajar pengetahuan yang berguna dan bermanfaat bagi agama, nusa dan bangsa.

Sesuai dengan penghasilannya suami menanggung :

a) Nafkah, kiswah dan tempat kediaman bagi isteri;

b) Biaya rumah tangga, biaya perawatan dan biaya pengobatan bagi isteri dan anak;

c) Biaya pendididikan bagi anak. ${ }^{33}$

Nafkah berarti "belanja". 34 Yang di maksutnya belanja di sini yaitu memenuhi kebutuhan makanan, tempat tinggal, pembantu rumah tangga, pengobatan istri, jika ia seorang kaya. ${ }^{35}$ Memberikan belanja kepada istri adalah wajib. Yang dimaksud dengan belanja, semua hajat dan keperluan yang berlaku menurut keadaan dan tempat, seperti makanan, pakaian, rumah dan sebagainya. ${ }^{36}$

Karena nafkah merupakan suatu kewajiban yang diberikan oleh suami kepada istri untuk memenuhi kebutuhan sehari-hari setelah diucapkannya ijab dan qobul.

31 Ahmad Warson Munawwir, Kamus Al Munawwir Arab- Indonesia.cet ke 20,( Surabaya: Pustaka Progressif, 2002), h. 1449. Nikah. h.144.

32 Sayyid Sabiq, Fiqih Sunnah Juz II, (Beirut: Darul Fikri, 2006). h. 539, lihat Al Hamdani, Risalah

33 Abdul Gani Abdullah, Pengantar Kompilasi Hukum Islam dalam Tata Hukum Indonesia, (Jakarta: Gema Insani Press, 1994), h. 101

34 Proyek Pembinaan Prasarana dan Sarana Perguruan Tinggi Agama/IAIN Jakarta, Ilmu Fiqh Jilid II, (Jakarta: Direktorat Jenderal Pembinaan Kelembagaan Agama Islam Departemen Agama. 1984/1985), h. 148.

35 Sayyid Sabiq, (Red) Moh. Tholib, Fikih Sunnah/Sayyid Sabiq, (Bandung: Alma'arif. 1997), h. 73.

36 Sulaiman Rasjid, Fiqih Islam, (Jakarta : Attahiriyah, 1996), h. 398. 
Di dalam Kamus Besar Bahasa Indonesia, nafkah adalah pendapatan suami yang wajib di berikan kepada istrinya. ${ }^{37}$

Syarat bagi perempuan/istri berhak menerima belanja dari suami adalah sebagai berikut ${ }^{38}$ : Ikatan perkawinannya sah, Menyerahkan dirinya pada suami, Suami dapat menikmati dirinya, Tidak menolak apabila di ajak pindah ke tempat yang dikehendaki suaminya, dan Kedua-duanya saling dapat menikmati.

Jika dalam hal ini salah satu syarat tidak terpenuhi maka istri tidak wajib diberi belanja oleh suami. Agama mewajibkan suami membelanjakan istrinya, karena adanya ikatan perkawinan yang sah itu seorang istri menjadi terikat kepada suaminya dan tertahan sebagai miliknya karena ia berhak menikmatinya secara terus-menerus. Istri wajib taat dan patuh pada suami, tinggal di rumah suami, mengatur rumah tangga, memelihara dan mendidik anak-anaknya. Dan sebaliknya suami berkewajiban memenuhi kebutuhan istri, dan memberikan belanja kepada istri, selama ikatan suami istri masih berjalan, dan istri tidak durhaka kepada suami.

Jika seorang istri tinggal bersama suaminya, maka sang suamilah yang menanggung nafkahnya dan bertanggung jawab mencukupi kebutuhannya, yang meliputi makanan, pakaian dan sebagainya. Maka dalam hal ini istri tidak perlu menuntut nafkah, karena suami wajib memenuhi kebutuhan istri, atau ia meninggalkan istri tanpa memberikan nafkah dengan tanpa alasan yang dibenarkan, maka istri berhak meminta ukuran nafkah yang meliputi makanan, pakaian, dan tempat tinggal, lalu pihak hakim menentapkan ukuran nafkah untuk si istri. Dan bagi suami harus melakukan keputusan hakim itu, jika dakwaan terhadapnya terbukti. $^{39}$

Adapun nafkah menurut istilah ulama fiqih adalah pengeluaran seseorang berupa kebutuhan kepada siapa yang wajib dinafkahinya, misalnya roti, pakaian, tempat tingggal dan apa yang dibutuhkanya. Hukumnya wajib, misalnya nafkah suami kepada istrinya atau nafkah bapak terhadap anaknya. ${ }^{40}$

Dari pengertian tersebut diatas seolah-olah nafkah hanya meupakan pemenuhan kepada istri dalam bidang materi. Namun lebih dari itu nafkah terbagi menjadi dua yaitu nafkah lahir (materi) dan nafkah batin atau hubungan biologis. ${ }^{41}$ Imam Malik mengatakan nafkah tidak wajib bagi suami sampai ia dapat mengajak untuk dukhul (wathi, jimak). 42

Dari pengertian tersebut di atas dapat disimpulkan, bahwa kewajiban seseorang untuk mengeluarkan nafkah kepada siapa yang berhak menerimanya, seperti suami berhak untuk memberi nafkah kepada istrinya, anak-anaknya bahkan nafkah yang utama diberi itu bertujuan untuk memenuhi kebutuhan pokok kehidupan, yakni makanan, pakaian dan tempat tinggal. Kewajiban memberi nafkah tersebut diberikan menurut kesanggupannya, hal ini dapat disesuaikan dengan kebutuhan dan kemampuan agar selaras dengan keadaan dan standar kehidupan mereka. Begitu pula terhadap kaum kerabat yang miskin, dan anak-anak

37 Tim Redaksi Kamus Besar Bahasa Indonesia, Kamus Besar Bahasa Indonesia, (Jakarta: PT Gramedia Pustaka Utama, 2008), h. 947.

38 Op.Cit., Sayyid Sabiq, (Red) Moh. Tholib, Fikih Sunnah /Sayyid Sabiq..., h. 76

39 Ahmad Tirmidzi, dkk, Ringkasan Fikih Sunnah Sayyid Sabiq, (Jakarta: Pustaka Al-Kautsar. 2013), h. 471

${ }^{40}$ Abdu al-Jaziri, al-Figh alal mazahibil al-arba'ah, Juz 4, Cet I (Daar al-afaq al-arabiah, al-Qahirah, 2005), h. 424

41 Ibid., Abdu al-Jaziri, al-Figh alal mazahibil al-arba'ah..., h. 424

42 Ibnu Rasyi Al Hafid, Bidayatul Mujtahid dan Nihayatul Muqtashid juz II, Jilid 1-6 bab Huququ Al Zaujiyah (Beirud: Dar Ibnu Asshahah, 2005), h. 44. 
terlantar. Sebuah keluarga sampai pada taraf atau tingkat tertentu wajib memberikan nafkah oleh yang bertanggung jawab terhadap keluarga itu. Hal ini sesuai dengan pendapat yang dikemukakan oleh Imam Hanafi yang bahwa: "Setiap keluarga sampai pada derajat atau tingkat tertentu berhak untuk dinafkahi, seandainya dia masih kanak -kanak dan miskin, lemah atau buta dan melarat".

\section{Nafkah Istri}

Nafkah isteri menjadi kewajiban bagi suami untuk memenuhinya dikarenakan sudah menjadi tanggungannya, nafkah kerabat wajib dipenuhi oleh kerabatnya disebabkan hubungan darah dan mahram, sedangkan nafkah seorang hamba wajib dipenuhi oleh tuannya disebabkan karena kepemilikan. ${ }^{43}$

Nafkah yang secara umum kita kenal adalah harta yang berupa makanan, pakaian, dan tempat tinggal yang diberikan kepada orang yang wajib diberinya. Adapun bentuk-bentuk nafkah menurut siapa yang wajib mengeluarkannya dan siapa yang menerimanya terbagi kepada lima orang, yaitu diantaranya:44 Nafkah istri. Adapun orang yang wajib memberinya nafkah adalah suaminya, baik istri yang hakiki seperti istri yang masih berada dalam perlindungan suaminya (tidak ditalak) atau istri secara hukum seperti wanita yang ditalak dengan talak raj'i sebelum masa iddahnya habis. Sebagaimana firman Allah SWT (QS. Al-Baqarah : 233) :



Artinya : Para ibu hendaklah menyusukan anak-anaknya selama dua tahun penuh, Yaitu bagi yang ingin menyempurnakan penyusuan. dan kewajiban ayah memberi Makan dan pakaian kepada Para ibu dengan cara ma'ruf. seseorang tidak dibebani melainkan menurut kadar kesanggupannya. janganlah seorang ibu menderita kesengsaraan karena anaknya dan seorang ayah karena anaknya, dan warispun berkewajiban demikian. apabila keduanya ingin menyapih (sebelum dua tahun) dengan kerelaan keduanya dan permusyawaratan, Maka tidak ada dosa atas keduanya. dan jika kamu ingin anakmu disusukan oleh orang lain, Maka tidak ada dosa bagimu apabila kamu memberikan pembayaran menurut yang patut. bertakwalah kamu kepada Allah dan ketahuilah bahwa Allah Maha melihat apa yang kamu kerjakan. (QS. Al-Baqarah : 233) ${ }^{45}$

Menjadi kewajiban suami untuk memberi nafkah istri menurut yang ma'ruf (patut). Adapun yang dinamakan patut disini adalah apa yang biasa dimakan oleh penduduk negeri dimana ia tinggal, baik berupa gandum, jagung, beras dan lainnya. Suami tidak dibebani untuk memberi nafkah selain makanan pokok yang umum selain di negeri ia tinggal. Sedangkan pakaian dan lauk pauk disesuaikan pula. Jika laki-laki tidak mampu memberi nafkah kepada istrinya, maka keduanya dapat dipisahkan. Kewajiban seorang laki-laki meberikan nafkah kepada seorang wanita

43 Muhammad Abu Zahrah, al-Ahwal al-Syakhshiyyah, (t.t, Dar al-Fikr al-„,Arabi, 1957), cet. III, h.

44 Syaikh Abu Bakar Jabir al-Jaza"iri, "Minhajul Muslim", terjemah Musthafa Aini dkk Cet. ke-1, (Jakarta: Darul Haq, 2006), h. 556

45 Departemen Agama RI, Al-Qur'an dan Terjemahannya, h. 37. 
apabila ia telah mengikat tali pernikahan dengannya dan tidak ada lagi halangan baginya untuk masuk menemui istrinya. Nafkah terhadap seorang istri dihentikan, jika ia membangkang, atau tidak mengizinkan suami menggaulinya.

Yusuf Qardhawi mengatakan fardhu ain yang berhubungan dengan hak Allah semata dapat ditolelir pelaksanaanya, berbeda dengan fardhu ain yang berhubungan dengan hak-hak manusia. Para ulama berpendapat, sesungguhnya hak-hak allah Ta"eala dibangun atas dasar toleransi, sementara hak-hak manusia dibangun atas dasar kepastian.

Oleh karenanya jika berdakwah diwajibkan dalam kalangan Jamaah Tabligh pengikiut Maulana Muhammad Ilyas maka memberikan nafkah matriil dan inmatriil kepada istri dan anak harus didahulukan. Karena sangat pentingnya hak-hak manusia disini khususnya hak istri mendapatkan nafkah dan perlindungan dari suaminya, maka benarlah hadits Nabi yang menyatakan bahwa mati syahid di jalan Allah, yang merupakan dambaan setiap muslim untuk lebih dekat kepada Tuhanya, tidak dapat menggugurkan kewajiban membayar hutang yang menjadikan kewajibanya. ${ }^{46}$

Nafkah merupakan hak dan kewajiban suami terhadap istri yang harus dipenuhi. Dalam al-Quran juga dijelaskan dalam QS. an-Nisa: 34

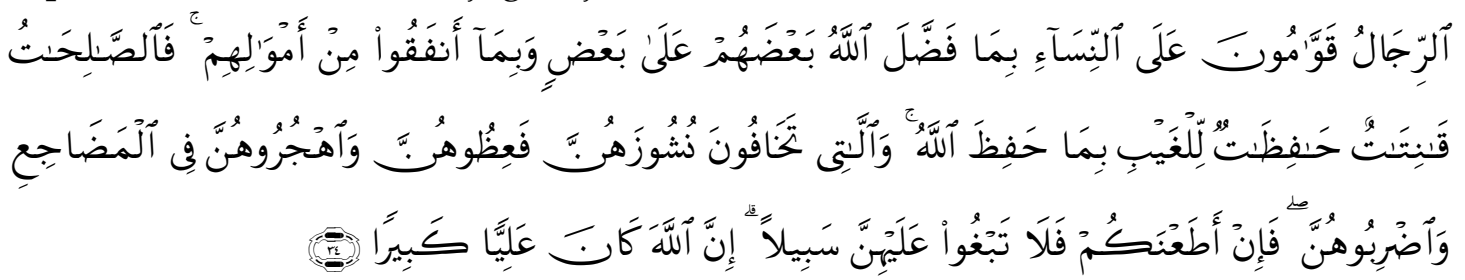

Artinya : "Kaum laki-laki itu adalah pemimpin bagi kaum wanita, oleh karena Allah telah melebihkan sebahagian mereka (laki-laki) atas sebahagian yang lain (wanita), dan karena mereka (laki-laki) telah menafkahkan sebagian dari harta mereka. sebab itu Maka wanita yang saleh, ialah yang taat kepada Allah lagi memelihara diritr ketika suaminya tidak ada, oleh karena Allah telah memelihara (mereka) ${ }^{48}$. wanita-wanita yang kamu khawatirkan nusyuznya,49 Maka nasehatilah mereka dan pisahkanlah mereka di tempat tidur mereka, dan pukullah mereka. kemudian jika mereka mentaatimu, Maka janganlah kamu mencari-cari jalan untuk menyusahkannya.50 Sesungguhnya Allah Maha Tinggi lagi Maha besar.

Hal itu karena nafkah adalah konpensasi menikmatinya, sehingga jika seorang suami tidak diizinkan menikmati istrinya maka nafkahnya secara otomatis dihentikan. Dalam penelitian ini terdapat dua macam nafkah terhadap Istri yaitu : Nafkah lahir (material) dan nafkah batin (immaterial).

a. Nafkah Lahir

46 Yusuf Qardhawi, Fikih Prioritas Urutan Amal Terpenting Dari yang Penting, (Jakarta: Gema Insani Press, 1996), h. 159

47 Maksudnya: tidak Berlaku curang serta memelihara rahasia dan harta suaminya.

48 Maksudnya: Allah telah mewajibkan kepada suami untuk mempergauli isterinya dengan baik.

49 Nusyuz: Yaitu meninggalkan kewajiban bersuami isteri. nusyuz dari pihak isteri seperti meninggalkan rumah tanpa izin suaminya.

50 Maksudnya: untuk memberi peljaran kepada isteri yang dikhawatirkan pembangkangannya haruslah mula-mula diberi nasehat, bila nasehat tidak bermanfaat barulah dipisahkan dari tempat tidur mereka, bila tidak bermanfaat juga barulah dibolehkan memukul mereka dengan pukulan yang tidak meninggalkan bekas. bila cara pertama telah ada manfaatnya janganlah dijalankan cara yang lain dan seterusnya. 
Nafkah lahir terhadap istri yang dimaksud disini adalah segala yang berkaitan dengan kebutuhan sehari-hari mulai dari makan, minum, pakaian, tempat tinggal, pengobatan, pembantu, sekiranya perlu. Nafkah isteri yang harus dipenuhi suami adalah sebagai berikut:

1) Sandang pangan

Kebutuhan sandang dan pangan merupakan tanggung jawab suami untuk memenuhinya. Hal ini berdasarkan firman Allah SWT :

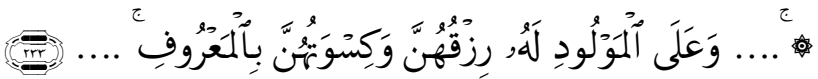

Artinya : "...Dan kewajiban ayah memberi Makan dan pakaian kepada Para ibu dengan cara ma'ruf...". (QS. Al-Baqarah: 233)51

Makanan menjadi kebutuhan pokok manusia bisa bekerja, beribadah, melakukan berbagai aktifitas manusiawi dengan baik, jika kebutuhan terhadap makanan tercukupi begitu juga dengan pakaian, menjadi penutup aurat, pelindung tubuh dan pelengkap ibadah.

2) Papan tempat tinggal

Rumah, sebagai tempat tinggal keluarga, juga menjadi kewajiban suami. Suami bertanggung jawab atas tersedianya papan (rumah) bagi keluarganya. Firman Allah SWT yang artinya :

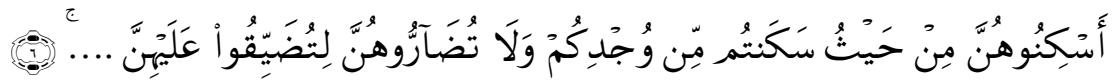

Artinya : "Tempatkanlah mereka (para isteri) di mana kamu bertempat tinggal menurut kemampuanmu dan janganlah kamu menyusahkan mereka untuk menyempitkan (hati) mereka...". (QS. At-Thalaq: 6) ${ }^{52}$

Papan merupakan sarana mutlak tempat bertemunya suami dan isteri, sebagai tempat istirahat melepaskan lelah, tempat mengasuh anakanak.

3) Pendidikan anak

Biaya pendidikan anak termasuk nafkah keluarga yang harus dipenuhi suami. Firman Alllah Swt :

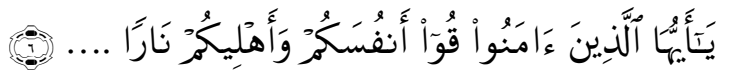

Artinya : "Hai orang-orang yang beriman, peliharalah dirimu dan keluargamu dari api neraka..." (QS. At-Tahrim: 6) ${ }^{53}$

Pendidikan merupakan sarana penting karena tiap manusia membutuhkan ilmu baik ilmu agama maupun ilmu sosial yang berkenaan dengan kehidupan maupun alam sekitar. Untuk memahami ilmu-ilmu tersebut, mereka harus belajar di lembaga-lembaga pendidikan, terutama zaman sekarang ini diperlukan biaya yang cukup. Maka dari itu biaya pendidikan anak-anak jugatermasuk nafkah keluarga yang mesti dipenuhi suami.

4) Biaya perawatan kesehatan

Kewajiban suami yang lain adalah menyediakan biaya perawatan kesehatan apabila isteri membutuhkan. Biaya perawatan kesehatan sama dengan kebutuhan pokok. Berkaitan dengan segala pemenuhan

53 Ibid., h. 560 
macammacam nafkah lahir di atas kewajiban memberi nafkah dalam hal ini suami mampu membayar nafkah isteri. Perlu memperhatikan hal-hal sebagai berikut :

a) Hendaklah jumlah nafkah itu mencukupi keperluan isteri dan disesuaikan dengan keadaan kemampuan suami, baik yang berhubungan dengan pangan, sandang maupun yang berhubungan dengan tempat tinggal.

b) Hendaknya nafkah ini ada pada waktu yang diperlukan. Oleh sebab itu hendaknya suami menentukan cara-cara dan waktuwaktu pemberian nafkah kepada isterinya; apa sekali seminggu, sekali sebulan, tiap waktu panen dan sebagainya.

c) Sebaiknya kadar nafkah itu didasarkan kepada jumlah kebutuhan pokok yang diperlukan, bukan berdasarkan jumlah uang yang diperlukan. Hal ini mengingat keadaan nilai uang yang kadangkadang mengalami perubahan atau harga barang kebutuhan pokok yang kadang-kadang naik atau turun.

Nafkah keluarga menyangkut nafkah istri, anak-anaknya (termasuk juga biaya pendidikannya), pembantu rumah tangga (kalau ada), dan semua orang yang menjadi tanggungannya seperti orang tua dan saudarasaudaranya yang tidak mampu menanggung nafkah, secara hukum juga menjadi tanggungan kepala keluarga yang bersangkutan. Allah tidak akan membebani seseorang di luar batas kemampuannya.

Meskipun kadar nafkah yang wajib diberikan suami sesuai dengan kemampuannya, akan tetapi hendaknya suami berusaha sekuat tenaga agar dapat memenuhi nafkah keluarga dan mengusahakannya secara halal, dan diperoleh dengan jalan yang baik pula, sehingga mendapatkan ridho Allah swt. Selain itu, suami juga tidak boleh bersikap kikir dalam memberikannya kepada orang-orang yang menjadi tanggungannya. Ia harus memberikannya dengan ikhlas dan hanya karena mengharap ridho Allah dan demi kebahagiaan keluarganya. ${ }^{54}$

b. Nafkah Bathin.

Berbicara tentang nafkah bathin Fiqih telah menjelaskan bahwasanya suami mempunyai kewajiban untuk memenuhinya. Sebagaimana kewajiban berbuat baik dalam hal lahir, suami juga berkewajiban berbuat baik dalam hal yang berhubungan dengan kebutuhan bathin istrinya, dan dalam hal ini berhubungan erat dengan kebutuhan biologis manusia. Hajat biologis merupakan kodrat pembawaan hidup dan termasuk kebutuhan vital diantara kebutuhan manusia yang lainnya. Kehendak ingin berhubungan seksual termasuk motif biogenesis bagi manusia yaitu kebutuhan untuk melanjutkan keturunan dan berkembang biak.

Firman Allah :

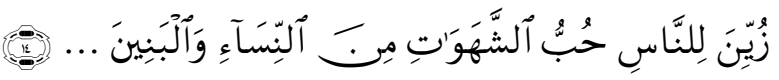

Artinya : "Dijadikan indah pada (pandangan) manusia kecintaan kepada apa-apa yang diingini, Yaitu: wanita-wanita, anak-anak..." (QS. Ali Imron : 14) 55

54 Fuad Kauma dan Nipan, Membimbing Istri Mendampingi Suami (Yogyakarta: Mitra Pustaka, 2003), h. 72

55 Op.Cit., Departemen Agama RI, Al-Qur'an dan Terjemahannya, h. 51. 
Islam merupakan agama yang telah mempunyai aturan yang komplek, termasuk juga dalam masalah ini. Ada beberapa etika yang berkenaan dengan hubungan seksual, dan salah satunya adalah larangan atau tidak dibenarkan pergaulan yang dapat merangsang kehendak seksual. Dikatakan bahwa rangsangan seksual yang tidak tersalurkan menyebabkan kegelisahan jiwa raga dan dapat membahayakan kesehatan.

Begitu juga dalam kehidupan rumah tangga. Ketenteraman dan keserasian hidup perkawinan antara lain ditentukan oleh faktor hajat biologis ini. Kekecewaan yang dialami dalam masalah ini dapat menimbulkan keretakan dalam hidup rumah tangga. Jelasnya, kepuasan bersetubuh adalah puncak kenikmatan biologis yang selalu diimpikan oleh setiap orang, terutama istri, maka seorang istri diperbolehkan minta cerai apabila kebutuhan yang satu ini tidak terpenuhi. Karena apabila diteruskan dan tidak ada upaya perubahan, dikhawatirkan istri akan patah semangat, bahkan melakukan tindakan selingkuh di luar rumah. ${ }^{56}$

Wajib bagi suami untuk mengumpuli istrinya minimal sekali pada masa sucinya, jika ia mampu untuk itu. Jika hal itu tidak dilakukan, maka sungguh ia telah bermaksiat kepada Allah. Demikian menurut Ibnu Hazm. Allah SWT berfirman dalam surat Al-Baqarah: 222.

Jumhur Ulama berpendapat sama seperti Ibnu Hazm, yaitu mewajibkan suami mencampuri strinya jika tidak ada halangan untuk itu. Sementara imam Asy Syafi'i mengatakan "tidak ada kewajiban bagi seorang suami untuk mencampuri istrinya. Karena hal itu merupakan haknya (suami) senagai hakhak lainya." 57

Sedangkan Imam Ahmad menetapakan hal itu dengan batas maksimal empat bulan, karena Allah telah menetapkannya bagi seorang tuan untuk tidak memberikan tidak memberikan makann budaknya. Demikian pada hakhak yang lain. Jika si suami bepergian dan meninggalkan istrinya, lalu tidak ada halangan baginya untuk pulang, maka dalam hal ini Imam Ahmad memberikan batas waktu enam bulan. 58

Imam Ghozali mengatakan "bahwa seorang suami harus mencampuri istrinya setiap empat malam sekali. Yang demikian itu adalah lebih adil, karena jumlah maksiat istri adalah empat. Sehingga diperbolehkan baginya mengakhirkan sampai batasan tersebut. Boleh juga lebih atau kurang dari itu, sesuai denga kebutuhan untuk memelihara mereka (para istrinya). Sebab memelihara mereka (para istri) juga merupakan kewajiban baginya (suami)." 59

Kompilasi Hukum Islam (KHI) tentang kewajiban suami kepada Istri terdapat dalam Pasal 77-81:60

\section{Pasal 77}

(1) Suami isteri memikul kewajiban yang luhur untuk menegakkan rumah tangga yang sakinah, mawaddah dan rahmah yang menjadi sendi dasar dari susunan masyarakat.

56 A. Azhar Basyir, Hukum Perkawinan Islam, 60-61. juga Fuad Kauma \& Nipan, Membimbing Istri, 63

57 Muhamad Uwaidah, Syah Kamil, Fiqih Wanita, (Jakarta: Pustaka Al Kaustar, 2008),441-443.

58 Ibid., h. 442

59 Ibid., h. 443

60 Abdurrahman, Kompilasi Hukum Islam di Indonesia, (Jakarta: CV Akademika Pressindo, 1995), h.114. 
(2) Suami isteri wajib saling cinta mencintai, hormat menghormati, setia dan memberi bantuan lahir batin yang satu kepada yang lain.

(3) Suami isteri memikul kewajiban untuk mengasuh dan memelihara anak-anak mereka, baik mengenai pertumbuhan jasmani, rohani maupun kecerdasannya dan pendidikan agamanya.

(4) Suami isteri wajib memelihara kehormatannya.

(5) Jika suami atau isteri melalaikan kewajibannya, masing-masing dapat mengajukan gugatan kepada pengadilan agama.

\section{Pasal 78}

(1) Suami isteri harus mempunyai tempat kediaman yang tetap.

(2) Rumah kediaman yang dimaksud dalam ayat (1) ditentukan oleh suami isteri bersama. ${ }^{61}$

\section{Pasal 80}

(1) Suami adalah pembimbing terhadap isteri dan rumah tangganya, akan tetapi mengenai hal-hal urusan rumah tangga yang penting-penting diputuskan oleh suami isteri bersama.

(2) Suami wajib melindungi isterinya dan memberikan segala sesuatu keperluan hidup rumah tangga sesuai dengan kemampuannya.

(3) Suami wajib memberikan pendidikan agama kepada isterinya dan memberi kesempatan belajar pengetahuan yang berguna dan bermanfaat bagi agama, dan bangsa.

(4) Sesuai dengan penghasilannya, suami menanggung:

(a) Nafkah, kiswah dan tempat kediaman bagi isteri

(b) Biaya rumah tangga, biaya perawatan dan biaya pengobatan bagi isteri dan anak.

(c) Biaya pendidikan bagi anak.

(5) Kewajiaban suami terhadap isterinya seperti tersebut apda ayat (4) huruf a dan b di atas mulai berlaku sesudah ada tamkin sempurna dari isterinya.

(6) Isteri dapat membebaskan suaminya dari kewajiban terhadap dirinya sebagaimana tersebut pada ayat (4) huruf a dan b.

(7) Kewajiban suami sebagaimana dimaksud ayat (2) gugur apabila isteri nusyus.

\section{Pasal 81}

Tentang Tempat Kediaman

(1) Suami wajib menyediakan tempat kediaman bagi isteri dan anak-anaknya, atau bekas isteri yang masih dalam iddah.

(2) Tempat kediaman adalah tempat tinggal yang layak untuk isteri selama dalam ikatan perkawinan, atau dalam iddah talak atau iddah wafat.

(3) Tempat kediaman disediakan untuk melindungi isteri dan anak-anaknya dari gangguan pihak lain, sehingga mereka merasa aman dan tenteram. Tempat kediaman juga berfungsi sebagai penyimpanan harta kekayaan, sebagai tempat menata dan mengatur alat-alat rumah tangga.

(4) Suami wajib melengkapi tempat kediaman sesuai dengan kemampuannya serta disesuaikan dengan keadaan lingkungan tempat tinggalnya,baik berupa alat perlengkapan rumah tangga maupun sarana penunjang lainnya.

61 Ibid., Abdurrahman, Kompilasi Hukum Islam di Indonesia...., h. 157-158. 
(1) Suami yang mempunyai isteri lebih dari seorang berkewajiban memberi tempat tinggal dan biaya hidup kepada masing-masing isteri secara berimbang menurut besar kecilnya keluaraga yang ditanggung masingmasing isteri, kecuali jika ada perjanjian perkawinan.

(2) Dalam hal para isteri rela dan ikhlas, suami dapat menempatkan isterinya dalam satu tempat kediaman. 62

\section{Nafkah Anak}

Nafkah anak. Orang yang wajib memberinya nafkah adalah adalah bapaknya. Hal ini sesuai berdasarkan firman Allah SWT (QS. An-Nissa:5) :



Artinya: "Dan janganlah kamu serahkan kepada orang-orang yang belum sempurna akalnya63, harta (mereka yang ada dalam kekuasaanmu) yang dijadikan Allah sebagai pokok kehidupan. berilah mereka belanja dan pakaian (dari hasil harta itu) dan ucapkanlah kepada mereka kata-kata yang baik. (QS. An-Nissa:5) ${ }^{64}$

Kewajiban member nafkah ada pada bapak bukan pada ibunya, baik ibunya telah bersuami atau pun telah ditalak. Dengan demikian, diketahui bahwa pemberian nafkah tidak seperti hukum warisan, karena sesungguhnya ibu termasuk ahli waris, kewajiban untuk member nafkah dan penyusuan dibebankan kepada bapak bukan kepada ibu. ${ }^{65}$ Nafkah terhadap anak laki-laki dihentikan jika ia telah baligh dan nafkah terhadap anak perempuan dihentikan jika ia telah menikah. Tapi dikecualikan bagi anak laki-laki yang telah baligh, jika ia menderita sakit atau gila, maka nafkah terhadapnya tetap masih menjadi tanggungan orang tuanya (Bapaknya).

\section{Gerakan Dakwah Pengertian}

Gerakan dakwah atau lebih sering dikenal dengan dakwah harakah bermakna dakwah dengan atau melalui sistem pergerakan. Sesuai dengan namanya, aliran dakwah yang satu ini lebih menekankan aspek tindakan (aksi) ketimbang wacana (teoritisasi). ${ }^{66}$ Menurut Hasan al-Qattany, yang dimaksud dakwah harakah adalah dakwah yang berorientasi pada pengembangan masyarakat Islam, dengan melakukan reformasi total (islah) terhadap seluruh aspek kehidupan social, baik terkait dengan individu (islah al-fard), keluarga (islah al-usrah), masyarakat (islah al-mujtama') hingga Negara (islah al-daulah). ${ }^{67}$

Kata Harakah itu sendiri secara harfiah berarti gerak atau gerakan, merupakan lawan dari diam (al-Harakah Dlidl al-Sukun). Dikatakan bergerak, bila

62 Ibid. Abdurahman, Kompilasi Hukum Islam di Indonesia..., h. 161-163

63 Orang yang belum sempurna akalnya ialah anak yatim yang belum balig atau orang dewasa yang tidak dapat mengatur harta bendanya.

64 Op.Cit., Departemen Agama RI, Al-Qur'an dan Terjemahannya ..., h. 77

65 Imam Syafi'i, Ringkasan Kitab Al-Umm, jilid 3-6, Terjemah Muhammad Yasir cet.ke-3, (Jakarta:Pustaka Azzam,2007), h. 440.

${ }^{66}$ Ilyas Ismail dan Prio Hotman, Filsafat Dakwah : Rekayasa Membangun Agama dan Peradaban Islam, (Jakarta : Prenada Media Group, 2011), Cet. Ke-1, h. 233

67 Hasan Ibn Falah al-Qattany, al-Tariq ila al-Nahdah al-Islamiyyah, (Riyad: Dar al-Hamidi, 1993), h. 1-10 
seorang berpindah atau mengambil posisi baru. ${ }^{68}$ Dan makna harfiah ini, dapat dipahami dua makna penting kata harakah. Pertama, haraka, menunjuk pada suatu gerakan yang timbul setelah masa atau kondisi vakum. Kedua, harakah menunjuk pada suatu usaha pembaruan untuk membawa masyarakat kepada kehidupan baru yang lebih baik. ${ }^{69}$

Harakah (movement), menurut Kalim Siddiqui, merupakan watak Islam. Dikatakan bahwa Islam (lahir) menjadi suatu gerakan dan akan selalu menjadi grakan. Gerakan Islam bertujuan mendirikan dan melindungi Negara Islam demi kesejahteraan dan kebahagiaan hidup di dunia maupun di akhirat. ${ }^{70}$ "The Islamic Movement is the struggle of The Muslims to establish, maintain, develop, devend, extend,or re-establish the Islamic state as an instrument to enjoin good and firbid evil for the walfare, and happiness for the mankind in this world and in the hereafter. ",t that the while Islamic state coud be lost, the Islamic movement itself was on-going and could no be lost."71

Dalam perkembangannya dakwah harakah dilihat dari segi substansi dan cakupannya, dakwah harakah mengklaim memiliki ruang gerak yang lebih komprehensif dari pada dakwah pengembangan masyarakat. Jika dalam perkembangannya dakwah harakah dalam melihat keterlibatan dan independensi dari unsur politik dan membatasi gerakanya lebih pada ruang lingkup pendidikan dan pembangunan ekonomi, namun dakwah harakah lebih menilai politik sebagai salah satu bagian yang tak terpisahkan dari sistem Islam, karena dakwah tidak bisa dilepaskan dari politik. Dalam pandangan paradigma harakah, Islam itu disimbolkan dengan 3D, din (agama), daulah (negara), dan dunya (dunia). ${ }^{72}$

Kemunculan paradigma dakwah bukan hanya belatar belakang doktrin tersebut ansich, tetapi juga ada factor historis, yakni keterpurukan umat Islam pasca kolonialisme di satu sisi, dan kebangkitan Islam disisi yang lain. ${ }^{73}$ Menurut Ibrahim al-Ja'bari, dakwah harakah sebagai paradigma yang memadukan dimensi pemikiran (konsepsional) dan pergerakan (praktikal), mulai eksis bermunculan di negeri-negeri Islam sejak permulaan abad ke-20 silam dan karenanya model-model dakwah ini banyak diadopsi, misalnya, pergerakan Islam kontemporer Ikhwanul Muslimin di Mesir, Nur Khuluq di Turki, Revolusi Islam di Iran, dan Jama' ati Islam di anak benua India-Pakistan. ${ }^{74}$

68 Raghib al-Ashfahani, al-Mufradat fi Gharib al-Qur'an, (Beirut Libanon : Dar al-Ma'rifah, tt.), h. 114. Lihat pula, Ibn Manzhur, Lisan al-Arab, (Beirut: Dar Shadir, 1990), Cet. Ke-1, h. 410-411

69 Ibid, Ibn Manzhur, Lisan al-Arab ..., h. 410-411

70 A. Ilyaz Ismail, Paradigma Dakwah Sayyid Quthub : Rekonstruksi Pemikiran Dakwah Harakah, (Jakarta : Permadani, 2006), Cet.Ke-1, h. 12-13

71 Simi Niazi, A New Paradigm in the Making, dalam Kalim Siddiqui (Ed.) Issues in the Islamic Movement 1980-1981 (1400-1401), (London-Toronto-Pretoria : The Open Press Limited, 1982), h. 330-331

72 Op.Cit., Ilyas Ismail dan Prio Hotman, Filsafat Dakwah..., h. 233

73 Yusuf al-Qardawy, Sahwat al-islamiyah wa Humun al-Watan al-'Arab wa al-Islami, (Kairo : Makhtabah Wahbah, 1997), h. 29

${ }^{74}$ Ibrahim Muhammad al-Ja'bari, Gerakan Kebangkitan Islam, alih bahasa Abu Ayyub al-Ansary, (Solo : Duta Rohman, 1996), h. 67-70 
Dari segi kebahasaan, kata harakah dapat diartikan sebagai gerak atau gerakan; arti ini dapat kata ini dapat dikontraskan dengan kata al-sukun yang berarti diam (din al-sukun). Dari pemahaman kebahasaan ini, sesuatu yang bergerak itu ditandai jika terdapat perpindahan dari suatu tempat atau itu kondisi ke tempat atau konsidi lainnya. Jika dikaitkan dengan dakwah, maka dakwah yang menghendaki pergerakan dari konsidi vakum sebelumnya, atau menghendaki suatu usaha pembaharuaan untuk membawa masyarakat kepada kehidupan baru yang lebih baik. ${ }^{75}$

Bagi pendukung mazhab ini harakah bukanlah sekedar pandangan atau penafsiran, lebih dari itu, harakah adalah watak dasar bagi suatu gerakan dan akan selalu menjadi gerakan. ${ }^{76}$ Islam tidak dibatasi hanya sebagai agamanya (din), tetapi juga harus diyakini sebagai aturan hidup bermasyarakat (dunya) dan aturan menjalankan pemerintahan (daulah). Paradigma dakwah harakah menegaskan perlunya meyakini Islam sebagai sistem hidup yang komprehensif (manhaj hayah). ${ }^{77}$

\section{Jama'ah Tabligh \\ Pengertian}

Kata Jamaah tabligh berasal dari bahasa Arab sedangkan secara pengertian adalah gerakan trasnasional yang bergerak dari kalangan bawah, kemudian merangkul seluruh masyaakat muslim tanpa memandang tingkatan sosial dan ekonominya dalam mendekatkan diri kepada ajaran islam sebagaimana yang dibawa oleh Nabi Muhammad Saw. ${ }^{78}$

Jamaah Tabligh didirikan pada akhir dekade 1920-an oleh Maulana Muhamma Ilyas Kandhalawi di Mewat, sebuah provinsi di India. Tabligh resminya bukan merupakan kelompok atau ikatan, tapi gerakan muslim untuk menjadikan muslim yang menjalankan agamanya dan hanya satu-satunya gerakan islam yang tidak memandang asal-usul madzhab atau aliran pengikutnya.

Motif berdirinya Jamaah Tabligh adalah sebuah keinginan kuat untuk memperbaiki kondisi umat, terutama daerah Mewat yang hidup jauh dari ilmu dan lekat dengan kebodohan serta keterbelakangan. Keadaan umat islam di sebagian besar dunia pada saat itu sudah rusak dan penuh dengan kebodohan, kefasikan dan kekufurran. Mereka benar-benar meniru tingkah laku jahiliyah yang pertama. ${ }^{79}$

${ }^{75}$ Abu Mufdal al-Raghib al-Ashifany, al-Mufradat fi Gharib Al-Qur'an, (Damaskus : Dar Qalam, tt.), Juz 1, h. 226

76 A. Ilyaz Ismail, Paradigma Dakwah Sayyid Quthub Rekonstruksi Pemikiran Dakwah Harakah, (Jakarta : Penamadani, 2006), h. 12

77 Muhammad al-Ghazali, Fi Maukib al-Da'wah, (Kairo : Maktabah Nahdah al-Misr, 2005), h.163

78 Ali Nadawi, Riwayat Hidup dan Usaha Dakwah Maulana M.Ilyas, (Yogyakarta: As-Shaff, 1999),

h. 5

79 Khusniati Rofiah, Dakwah Jamah Tabligh \& Eksistensinya Di Masyarakat, (Ponorogo: Press, 2010), h. 54-55. 
Di indonesia, Jamaah Tabligh berkembang sejak 1952 dibawa oleh rombongan dari India yang dipimpin oleh Miaji Isa. Tapi gerakan ini mulai marak pada awal 1970.80 Didalam Jamaah Tabligh, masing-masing bermadzhab menurut keyakinan masing-masing. Ada yang bermadzhab Hanafi, Maliki, Hambali ataupun Madzhab Syafii seperti kebanyakan kaum muslimin di Indonesia, Malaysia, Singapura, Bruney Darussalam, Philipina, dan Sekitarnya.

Tidak mungkin mereka itu tidak bermadzhab. Walaupun diakai sebagaimana masyarakat awam pada umumnya, bahwa kalangan awam Jamaah Tabligh tidak mengikuti ajaran madzhab mereka secara patuh. Hal itu karena ketidak sempatan mereka untuk memperdalam masalah madzhab, sehingga mereka mengikuti sekedar pengetahuan mereka. Namun demikian, secara umum mereka tetap mengikuti arahan dan bimbingan alim ulama masingmasing ditempat mereka. ${ }^{81}$

Walaupun Jamaah Tabligh tidak memiliki organisasi secara formal, namun kegiatan dan anggotanya terkoodinir dengan baik sekali. Bahkan mereka memilki detabase lengkap sekali. Dimulai dari penanggung jawab mereka untuk seluruh dunia yang dikenal dengan Ahli Syura di Nizamudin, New Delhi, India. Pimpinan mereka disebut Amir atau Zamidar atau Zumindar. Kemudian dibawahnya ada Syura Negara, misalnya: Indonesia, Malaysia, Amerika dan lain-lain. Menurut pengaukuan mereka ada lebih dari 250 negara yang memiliki markaz seperti masjid kebon jeruk Jakarta. ${ }^{82}$

Setiap 4 bulan mereka berkumpul musyawarah Negara masing-masing kemudian dibbwa ke musyawarah dunia di Nizamuddin. Musyawarah harian ada di mahalah masing-masing untuk memikirkan orang kampung mereka masing-masing sehingga biarpun ada yang pergi tasykil tetaplah ada orang di maqami yang menganggap dakwah di sana. Jamaah ini mengklaim mereka tidak menerima donasis dana dari manapun untuk menjalankan aktivitasnya. Biaya oprasional Tabligh dibiayai ssendiri oleh pengikutnya. ${ }^{83}$

Jama'ah Tabligh merupakan sekelompok atau segolongan kaum yang menyeru kepada yang ma'ruf dan mencegah dari yang mungkar, menyampaikan (tabligh) seruan Allah dengan landasan iman (laillaha ila llah). Agar iman tertanam dalam setiap diri dan tercipta lah rahmatan lil alamin yang dilandasi oleh Al-Qur'an dan hadits. Jama'ah Tabligh adalah jama'ah yang sangat intens melakukan dakwah. 84

Maulana Muhammad Ilyaz rahmatullah alaih ketika melulai kegiatan dakwah tabligh ini mengatakan "Aku tidak memberikan nama apa pun terhadap usaha ini. Tetapi, seandainya aku memberinya nama, tentu aku menamakannya 'gerakan iman'." Beliau menyadari bahwa memberikan suatu nama khusus pada

80 Ibid., h. 56

81 Abdurrahman Ahmad As-Sirbuny, Kupas Tuntas Jama"ah Tabligh, (Cirebon: Pustaka Nabawi, 2012), h. 127

82 Op.Cit, Khusniati Rofiah, Dakwah Jama'ah Tabligh E Eksistensinya Di Mata Masyarakat..., h. 56

83 Ibid., Khusniati Rofiah, Dakwah Jama'ah Tabligh \& Eksistensinya Di Mata Masyarakat..., h. 56

84 Ibid.,Khusniati Rofiah, Dakwah Jama'ah Tabligh \& Eksistensinya Di Mata Masyarakat..., h. 78 
kegiatan ini berarti membuat pengelompokan baru pada ummat. Ada umat yang aggota dan yang bukan anggota.Sedangkan dakwah dan tabligh adalah suatu amal ibadah seperti shalat, puasa, dzikir, dan sebagainya.Sebagaimana dalam ibadah-ibadah lain tidak ada pengelompokan dan keanggotaan (misalnya kelompok ahli shalat, ahli puasa dan lain-lain) demikian pula halnya dengan dakwah tablgih.

Selain hal itu, dakwah adalah tanggung jawab setiap individu ummat ini yang harus mereka tunaikan tanpa kecuali. Bila bentuk satu kelompok dakwah, tentu akan timbul bahwa dakwah adalah tugas anggota kelompok dakwah saja. Dengan berbagai pertimbangan itu Maulana Ilyaz tidak memberikan nama terhadap usaha dakwah tablgih.

Sedangkan "Jama'ah Tabligh" hanyalah sebutan untuk memudahkan saja.Sebutan tersebut bukan berarti ada anggota dan ada yang bukan anggota. Orang-orang mengikuti program keluar selama beberpa hari, setelah selesai akan kembali ketempat tinggalnya dan menjalankan aktifitas sebagaimana biasa, di tambah dengan usaha untuk berdakwah kepada orang-orang di sekitarnya.

"Jaulah" dalam bahasa Arab berarti keliling. "Jaulah"sendiri sebenarnya adalah satu program yang dilakukan setiap hari oleh jama'ah yang sedang keluar.Program serupa diadakan juga seminggu sekali di rumah-rumah sekitar masjid sendiri. Satu rombongan terdiri dari lima sanpai sepuluh orang mendatangi tiap-tiap rumah, menyampaikan pentingnya iman, amal shaleh, dan mengundang laki-laki penghuni rumah mengikuti program muzakarah dan kultum di masjid. Program ini biasanya dilakukan setelah Ashar hingga menjelang Maghrib. 85

Dari penjelasan diatas Jama'ah Tabligh bukan lah nama dari gerakan ini, namun Jama'ah Tabligh hanyalah sebutan yang berasal dari masyarakat untuk memudahkan mengingat, keberadaan gerakan yang menyampaikan (tabligh) agama kepada ummat seluruh alam. Karena awal mula gerakan ini dibuat oleh Maulana Ilyaz rahmatullah alaih di Mewat, India saat itu tidak diberi nama. Jika gerakan ini diberi nama niscaya beliau akan menamai dengan gerakan Iman untuk membentuk sifat yakin kepada Allah Swt.

\section{Simpulan}

Berdasarkan hasil penelusuran dan pembahasan tentang analisis hukum nafkah dalam keluarga Gerakan Dakwah Jama'ah Tabligh, dapat ditarik kesimpulan bahwa:

Dalam hukum positif Indonesia, permasalahan nafkah atau pemenuhan kebutuhan keluarga juga telah diatur dan dinyatakan menjadi kewajiban suami. Hal ini sesuai dengan Undang-undang No. 1 Tahun 1974, pasal 34 ayat (1) dan dipertegas oleh KHI Pasal 80 ayat (4). Keberadaan nafkah tentu mempunyai pengaruh dan fungsi yang sangat besar dalam membina keluarga yang bahagia,

85 Mulwi Ahmad Harun Al-Rosyid, Meluruskan Kesalahpahaman Terhadap Jaulah (Jama'ah Tabligh), (Magetan : Pustaka Haromain, 2004), Cet. Ke-2, h.22 
tenteram dan sejahtera. Tidak terpenuhi nafkah sama sekali atau nafkah yang tidak cukup dapat berakibat krisis perkawinan yang berujung pada perceraian.

Suami harus memprioritaskan hak istri dan anaknya baik materil (lahir) maupun immaterial sebelum menginggalkan keluarga untuk melaksanakan khuruj fii sabilillah (keluar di jalan Allah) 3 hari, 40 hari, 4 bulan seperti yang disebutkan oleh Yusuf Qardawi dalam fikih prioritas yaitu mengutamakan hakhak manusia atas hak-hak Allah. Dan berdasarakan Kompilasi Hukum Islam (KHI) tentang kewajiban suami terhadap isteri pasal 80 ayat 4a. Selama suami dapat memenuhi hak dan kewajibannya pada pasal tersebut saat melakukan kegiatan khuruj fii sabilillah maka tidak akan terdapat penyimpangan yang dilakukan oleh Jamaah tabligh.

\section{Referensi}

A. Azhar Basyir, Hukum Perkawinan Islam. juga Fuad Kauma \& Nipan, Membimbing Istri

A. Ilyaz Ismail, Paradigma Dakwah Sayyid Quthub : Rekonstruksi Pemikiran Dakwah Harakah, (Jakarta : Permadani, 2006), Cet.Ke-1,

Abdu al-Jaziri, al-Figh alal mazahibil al-arba'ah, Juz 4, Cet I (Daar al-afaq al-arabiah, alQahirah, 2005)

Abdul Gani Abdullah, Pengantar Kompilasi Hukum Islam dalam Tata Hukum Indonesia, (Jakarta: Gema Insani Press, 1994)

Abdurrahman Ahmad As-Sirbuny, Kupas Tuntas Jama"ah Tabligh, (Cirebon: Pustaka Nabawi, 2012)

Abdurrahman al-Jaziri, kitab al-Figh "ala Madzhabi al-Arba"ah, (Beirut: Dar al-Kutub al-,Ilmiyah, 1969), juz. IV

Abdurrahman, Kompilasi Hukum Islam di Indonesia, (Jakarta: CV Akademika Pressindo, 1995)

Abu Mufdal al-Raghib al-Ashifany, al-Mufradat fi Gharib Al-Qur'an, (Damaskus : Dar Qalam, tt.), Juz 1

Ahmad Rofiq, Hukum Isslam di Indoneia, cet. Ke-2, (Jakarta: PT Raja Grafindo Persada, 1997)

Ahmad Tirmidzi, dkk, Ringkasan Fikih Sunnah Sayyid Sabiq, (Jakarta: Pustaka AlKautsar. 2013)

Ahmad Warson Munawir, Kamus al Munawwir, (Yogyakarta: Pondok Psantren al Munawwir, 1984)

Ahmad Warson Munawwir, Kamus Al Munawwir Arab- Indonesia.cet ke 20,( Surabaya: Pustaka Progressif, 2002)

Ali Nadawi, Riwayat Hidup dan Usaha Dakwah Maulana M.Ilyas, (Yogyakarta: AsShaff, 1999)

Aliy As'ad, Terjemahan Fat-Hul Mu'in, Jilid 3, Menara Kudus, t.t,

As-Sayyid Muhammad Rasyid Ridha, Risalah Hak dan Kewajiban Wanita, alih bahasa Isnando (Jakarta: Pustaka Qalami, 2004)

As-Sayyid Sabiq, Fiqih as-sunnah, alih bahasa. Moh Thalib, cet. Ke-13 (Bandung: AlMa'arif, 1997), VII

Departemen Agama RI, Al-Qur'an dan Terjemahannya

Diknas, Kamus Besar Bahasa Indonesia, (Jakarta: Balai Pustaka, 2002), Edisi ketiga 
Fuad Kauma dan Nipan, Membimbing Istri Mendampingi Suami (Yogyakarta: Mitra Pustaka, 2003)

Hasan Ibn Falah al-Qattany, al-Tariq ila al-Nahdah al-Islamiyyah, (Riyad : Dar alHamidi, 1993)

Ibnu Manzhur. Lisãn al- Arab. Jilid. 4 ( Bairut: Dãr-Elfikr. 1990)

Ibnu Rasyi Al Hafid, Bidayatul Mujtahid dan Nihayatul Muqtashid juz II, Jilid 1-6 bab Huququ Al Zaujiyah (Beirud: Dar Ibnu Asshahah, 2005)

Ibrahim Muhammad al-Ja'bari, Gerakan Kebangkitan Islam, alih bahasa Abu Ayyub al-Ansary, (Solo : Duta Rohman, 1996

Ilyas Ismail dan Prio Hotman, Filsafat Dakwah : Rekayasa Membangun Agama dan Peradaban Islam, (Jakarta : Prenada Media Group, 2011), Cet. Ke-1

Imam Syafi'i, Ringkasan Kitab Al-Umm, jilid 3-6, Terjemah Muhammad Yasir cet.ke3, (Jakarta:Pustaka Azzam,2007)

Khusniati Rofiah, Dakwah Jamah Tabligh \& Eksistensinya Di Masyarakat, (Ponorogo: Press, 2010)

Muhamad Uwaidah, Syah Kamil, Fiqih Wanita, (Jakarta: Pustaka Al Kaustar, 2008)

Muhammad Abu Zahrah, al-Ahwal al-Syakhshiyyah, (t.t, Dar al-Fikr al-„Arabi, 1957), cet. III

Muhammad al-Ghazali, Fi Maukib al-Da'wah, (Kairo : Maktabah Nahdah al-Misr, 2005)

Muhammad Jawad Mugniyah, Figh Lima Mazhab, Cet. 12 (Jakarta: Lentera, 2001)

Mulwi Ahmad Harun Al-Rosyid, Meluruskan Kesalahpahaman Terhadap Jaulah (Jama'ah Tabligh), (Magetan : Pustaka Haromain, 2004), Cet. Ke-2

Munir Fuady, Konsep Hukum Perdata, PT Raja Grafindo Persada, (Jakarta: 2014)

Proyek Pembinaan Prasarana dan Sarana Perguruan Tinggi Agama/IAIN Jakarta, Ilmu Fiqh Jilid II, (Jakarta: Direktorat Jenderal Pembinaan Kelembagaan Agama Islam Departemen Agama. 1984/1985)

Raghib al-Ashfahani, al-Mufradat fi Gharib al-Qur'an, (Beirut Libanon : Dar alMa'rifah, tt.) Lihat pula, Ibn Manzhur, Lisan al-Arab, (Beirut : Dar Shadir, 1990), Cet. Ke-1

Sayyid Sabiq, (Red) Moh. Tholib, Fikih Sunnah/Sayyid Sabiq, (Bandung: Alma'arif. 1997)

Sayyid Sabiq, Fiqih Sunnah Juz II, (Beirut: Darul Fikri, 2006), lihat Al Hamdani, Risalah Nikah

Simi Niazi, A New Paradigm in the Making, dalam Kalim Siddiqui (Ed.) Issues in the Islamic Movement 1980-1981 (1400-1401), (London-Toronto-Pretoria : The Open Press Limited, 1982)

Subaidi, Konsep Nafkah Menurut Hukum Perkawinan Islam, Vol. 1 No. 2 (Desember, 2014)

Sulaiman Rasjid, Fiqih Islam, (Jakarta : Attahiriyah, 1996)

Syaikh Abu Bakar Jabir al-Jaza"iri, "Minhajul Muslim", terjemah Musthafa Aini dkk Cet. ke-1, (Jakarta: Darul Haq, 2006)

Syamsuddin Muhammad bin Muhamamd al-Khatin al-Syarbini, Mugni al-Muhtaj, (Bairut: Dar-al-Kutub al-Ilmiyah, tt), Juz V,

Syamsul Bahri, Konsep Nafkah dalam Hukum Islam, No. 66, Th. XVII (Agustus, 2015)

Syariffuddun Amir, Hukum Perkawinan Islam di Indonesia, (Jakarta: Kencana, 2014)

Tim Redaksi Kamus Besar Bahasa Indonesia, Kamus Besar Bahasa Indonesia, (Jakarta: PT Gramedia Pustaka Utama, 2008) 
Wahbah al-Zuhaili, al-Figh al-Islam wa Adillatuhu, (Beirut: Dar al-Fikr, 1989), jilid II, cet. II

Al-Figh Al-Islam Wa'dillatuhu jilid X Terrjemahan Abdul Hayyi al-Qotani dkk, (Jakarta: Gema Insani \& Darul Fikir, 2011) Al- Fiqh asy-Syafi'I al-'Ami, Terjemahan Muhammad Afifi dan Abdul Aziz, jilid III, cet. I, (Jakarta: Al-Mahira, 2010)

Yusuf al-Qardawy, Sahwat al-islamiyah wa Humun al-Watan al-'Arab wa al-Islami, (Kairo : Makhtabah Wahbah, 1997)

Fikih Prioritas Urutan Amal Terpenting Dari yang Penting, (Jakarta: Gema Insani Press, 1996)

Zainal Abidin S dan Ibnu Mas'ud, Fiqih Madzhab Syafi'I (Bandung: Pustaka Setia, 2007) 